\title{
College of DuPage receives ACRL award
}

On May 10, the College of DuPage Library held an award reception to celebrate winning the first annual ACRL Excellence in Academic Libraries Award in the Community or Junior College division.

Sponsored by Blackwell's Information Services, the award recognizes academic libraries whose staffs have teamed in the development of innovative, creative, and visionary programs that deliver outstanding services and resources to further the education missions of their institutions.

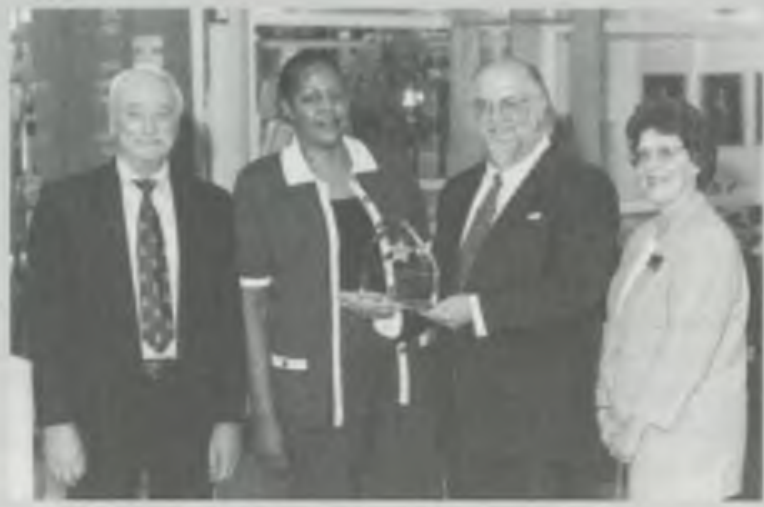

Blackwell's Donald Satisky and ACRL's Althea H. Jenkins presented the award to College of DuPage Library Director Bernard Fradkin and Mary Wuttke Kranz, chair of COD's Board of Trustees.

\section{College of DuPage President Michael T.} Murphy opened the program, addressing an enthusiastic audience of library staff, students, and members of the College of DuPage community. ACRL Executive Director Althea $H$. Jenkins presented the crystal trophy to Mary Kranz, chair of the Board of Trustees, and noted that the College of DuPage had been selected to receive the award from among nine finalists in its category. Donald Satisky, vice-president of Blackwell's, presented the $\$ 3,000$ check to Library Director Bernard Fradkin.
Reflecting on the award, Fradkin commended the library staff, and remarked that the Excellence in Academic Libraries award "provides a forum to discuss many of the programs and opportunities we have developed in extending the library to an extencled community. We are fortunate in seeking to in clu de older adults, business and corporate constituencies, and ethnically diverse patrons into our program. In addition, we are proud of our out$r$ e a c h through national teleconferencing, LTA Illinois, Ameritech, and the Chicago Donor's Forum." He noted that "while we are innovative in many ways, we have not lost track of the essential support provided through 'bread-and-butter' services and especially information literacy. The 1 brary staff is proud of its contributions and because of this special recognition we hope to continue researching new ways to offer the best the library profession can provide."

ACRL congratulates the College of DuPage on its achievement. - Meredith Parets, ACRL program assistant, mparets@ala.org

\section{New back issue finder}

Back Issue Finder (http://www. BackIssueFinder.com) has launched a new Web marketplace dedicated to locating and selling periodicals and ephemera. Back Issue Finder offers a searchable database of more than 230,000 items for sale from hundreds of sellers around the world. Back Issue Finder is a division of Sheboygan, Wisconsin-based Book Link, an out-of-print and remainder online bookseller.

\section{Send us your news}

CERL News wants to hear about your special events, programs, services, product selections, fundraising plans, buildings, etc. (we also love to get photos of these events) Make sure CERl Neus is on your mailing list for press releases and library newsletters. Send copies to CGRL News ACRL/ALA, 50 E. Huron St., Chicago, IL 60611 or e-nail: medavis@ala.org. 